\title{
Sir Desmond Pond
}

The College now boasts four members on whom the accolade of knighthood has been bestowed. Professor Desmond Pond was so honoured in the recent New Year Honours List.

The citation in The Times reads simply: 'President of the Royal College of Psychiatrists'. It is a fair assumption that his presidency of the College was in some measure responsible for the conferment of this high honour and the entire membership is entitled, therefore, not only to rejoice, but to bathe in the reflected glory.

But Sir Desmond has other claims to fame. His distinguished academic career was crowned by his election to the Chair of Psychiatry at the London Hospital in 1966. Such is his fame and prestige that his insatiable zest for foreign travel has been satisfied by the acceptance of invitations from a variety of countries both to lecture and to act in an advisory capacity. Thus, he has visited the USA (where he at one time held a Rockefeller Studentship at Duke University, North Carolina); South Africa; Hong Kong and very recently, mainland China. The paper he read at the last
Quarterly Meeting on his visit to China was an instructive and entertaining tour de force.

His numerous publications reflect his wide interests and include papers and chapters on epidemiology; the psychiatric aspects of epilepsy; brain damage in adults and children; narcolepsy; electroencephalography and social psychiatry.

Before his election to the presidency in 1978 he served the College well as an examiner for the MRCPsych, and as a member of Council and of the Court of Electors. It was during his term of office that he was appointed chairman of the Conference of Presidents of Royal Colleges and Faculties, the first psychiatrist to enjoy the distinction.

Sir Desmond wears his various decorations and chains of office lightly. He is good humoured and has a kindliness and an almost boyish ebulliance. In committee he is patient and leads rather than drives, while meetings under his chairmanship are brisk and accompanied by few Homeric nods.

He is in truth a verray parfit gentil knight.

HENRY R. ROLLIN

\section{President's Press}

I must start by saying, 'Thank you' to the many Members and Fellows of the College who have written and spoken such kind words of congratulation. It is of course an honour for psychiatrists as a whole, because so many of you have contributed to raising the status of our specialty, so the Presidential honour shows how widely this is now recognized. My warmest thanks to you all.

As you will have seen from a note in a previous Bulletin, I have become Chairman of the Conference of the Medical Royal Colleges and their Faculties in the UK. This grandiose title refers to a committee consisting of the Presidents of the medical Royal Colleges and the variously named Heads of the Faculties. It was formed a few years ago, mainly because the multiplicity of such independent organizations appearing in the last twenty years or so meant that a host of problems common to us lacked a forum in which they could be discussed. When Sir Douglas Black asked me to succeed him in the chair, I assumed that it was a nice gentle job, partly because of the consummate unobtrusive way in which Sir Douglas always conducts his business. Instead, within a few weeks, it turned out to be a very hot seat indeed because of the notorious Panorama programme on brain death. We were involved because the Conference, then chaired by Lord Smith, had been the organization which put forward the original criteria for brain death, so it was we who had to make the main protest to the BBC.

The Conference is a purely consultative and advisory body without formal or executive status, in contrast to the Joint Consultants' Committee. These two bodies also differ in membership, for example, the Conference has on it the President of the Royal College of General Practitioners, currently Dr John Horder, though he, of course, does not sit on the JCC. We also have, by invitation, some observers from the BMA and JCC. From time to time there has been pressure for us to become a sort of Academy of Medicine, an overlord body concerned with medical education, standards, etc. This issue was raised, for example, by the House of Commons Select Committee on medical education and staffing to which we recently gave evidence. They were concerned about the multiplicity of bodies involved in medical education, such as, the Council for Postgraduate Medical Education (CPME), the Department of Health which provides the training posts, the Royal Colleges which are examining bodies, the Universities which participate in postgraduate education and the General Medical Council which now deals with the registration of specialists as well as the General Register of all doctors. At the present time I don't think there is much drive for such a body, since the various organizations concerned with education have, of course, overlapping membership. Much the same people wear different hats while sitting on different committees. Lastly, bodies like the Royal Colleges and the Universities are understandably jealous of their independence and both would certainly be very wary of any committee on which they sat with equal rights as the representatives of state institutions like the Department of Health.

Amongst numerous matters that have gone through our (Continued on page 80) 